\title{
CORPOS, GÊNEROS E SEXUALIDADES EM DISPUTA NO BRASIL CONTEMPORÂNEO: BOLSONARISMO VERSUS TROPICALISMO
}

\author{
Bodies, genders and sexualities in dispute in \\ contemporary Brazil: Bolsonarism versus Tropicalism
}

\author{
André Duarte ${ }^{1}$ \\ Maria Rita de Assis César ${ }^{2}$
}

\begin{abstract}
RESUMO
A partir de uma chave teórica filosófico-política de inspiração benjaminiana, discutimos o atual embate em torno aos significados atribuídos aos corpos, gêneros e sexualidades no Brasil, contextualizando a discussão no marco da história brasileira recente. Sem proceder a uma análise exaustiva acerca da história política e cultural brasileira, abordamos o referido confronto a partir da formulação de duas imagens alegóricas, as quais condensam e imantam duas formas opostas de viver, nas quais os corpos, gêneros e sexualidades recebem especial atenção, porém a partir de duas perspectivas valorativas contrapostas entre si: uma que denominaremos de bolsonarista e outra que chamaremos de tropicalista. Consideramos que o modo como os corpos, gêneros e sexualidades são vividos atualmente constitui um aspecto decisivo para a qualificação do potencial e dos riscos políticos que assediam a democracia brasileira na atualidade.
\end{abstract}

Palavras-chave: Bolsonarismo; Tropicalismo; Corpos; Gêneros; Sexualidades; Democracia.

1 Professor Titular do Departamento de Filosofia da Universidade Federal do Paraná (UFPR), Brasil. É Professor do Programa de Pós-Graduação em Filosofia da UFPR e do Programa de Pós-Graduação em Educação da UFPR. Bolsista de Produtividade do CNPq 1-C. E-mail: andremacedoduarte@yahoo.com.br. ORCID: https://orcid.org/0000-0002-8401-0032

2 Professora Titular do Departamento de Teoria e Prática de Ensino da Universidade Federal do Paraná (UFPR), Brasil. É Professora do Programa de Pós-Graduação em Educação da UFPR. Bolsista de Produtividade do CNPq 2. E-mail: mritacesar@yahoo.com.br. ORCID: https://orcid.org/0000-0002-5843-2899 


\begin{abstract}
Freely inspired by a Benjaminian philosophical-political standpoint, we discuss the current Brazilian clash around the meanings attributed to bodies, genders and sexualities, contextualizing the discussion within the framework of recent Brazilian history. We do not provide an exhaustive analysis about the recent political and cultural Brazilian history; rather, we approach that clash by formulating two allegorical images, which condense and magnetize two opposite ways of living, in which bodies, genders and sexualities receive two opposed valuing perspectives: one that we shall call "bolsonarism", and another that we shall call tropicalism. We consider that the way such experiences about the bodies, genders and sexualities are lived constitute a decisive aspect for the qualification of the potential as well as the political risks that beset Brazilian democracy today.
\end{abstract}

Key-words: Bolsonarism; Tropicalism; Bodies; Genders; Sexualities; Democracy.

Quando o portuguez chegou

Debaixo de uma bruta chuva

Vestiu o índio

Que pena!

Fosse uma manhã de sol

O índio

Teria despido

O portuguez.

(Oswald de Andrade)

Como todo movimento explosivo, o tropicalismo deixou estilhaços em diversos lugares da cultura brasileira e, à medida que o tempo passa, descobrem-se fragmentos que ainda fervilham e geram novos focos de criação de alguma forma tributários daquele final dos anos 60 .

(Luiz Tatit)

O páthos deste trabalho: não há épocas de decadência.

(Walter Benjamin)

É difícil abordar a temática dos corpos, gêneros e sexualidades no Brasil sem incidir em velhos e bem estabelecidos clichés relativos a uma suposta identidade nacional. Durante décadas, talvez mesmo por séculos, 
construíram-se narrativas segundo as quais seríamos um povo abençoado ou amaldiçoado em função do lugar decisivo que corpo, gênero e sexualidade ocuparam em nossa história, evidenciado já desde a carta escrita no 21 de abril de 1500 por Pero Vaz de Caminha. Lembremo-nos do zelo minucioso com que descreveu ao rei D. Manuel os "bons corpos" e os rostos e narizes "bem-feitos" dos primeiros "mancebos" avistados na praia, além da criteriosa descrição daquelas três moças "bem gentis, com cabelos muito pretos, compridos pelas espáduas, e suas vergonhas tão altas, tão cerradinhas e tão limpas das cabeleiras" (CAMINHA, pp. 3 e 4, s.d.), para não falar daquela outra, que os portugueses tentaram vestir durante a primeira missa, mas sem sucesso. Está claro que desde o primeiro dia o invasor português não teve olhos apenas para os tesouros que aquelas matas frondosas pudessem ocultar, mas também para os corpos que seriam prontamente transformados em força de trabalho escravizada e em fonte de prazeres extorquidos, deixando marcas perenes em nossa história.

Contudo, se é inegável que corpos, gêneros e sexualidades sempre estiveram no centro de construções narrativas visando definir quem somos, parece-nos importante não seguir a trilha daqueles argumentos que construíram o mito de uma suposta liberdade sexual e corporal que, entre nós, jamais teria sido totalmente domesticada pelo invasor católico; nem tampouco os argumentos acerca de uma repressão sexual continuada, a qual teria feito de nós uma sociedade hipócrita com relação ao corpo e seus prazeres, cindindo-nos entre aquilo que dizemos publicamente e aquilo que fazemos em privado. Há certamente muito de verdadeiro e de falso nesses dois diagnósticos distintos, mas talvez complementares. O problema com as narrativas que visam construir a identidade sexual brasileira é o de que elas correm o risco de aprisionar e imobilizar o pensamento e a ação numa rede de generalizações conceituais e de teorizações de sobrevoo que, ou bem nos prometem o paraíso, ou bem nos ameaçam com os horrores do inferno, colocando-nos diante de possibilidades extremas diante das quais pouco resta o que fazer. Em uma palavra, a metafísica da identidade despolitiza o pensamento, pois perde de vista o palco das lutas políticas situadas, com seus matizes, inversões e reversões, invenções e ressignificações.

A partir de uma chave teórica filosófico-política de inspiração benjaminiana, discutimos neste texto o atual embate em torno dos significados atribuídos aos corpos, gêneros e sexualidades no Brasil, contextualizando a questão no marco dos últimos 50 anos da história brasileira. Sem proceder a uma análise exaustiva acerca da história política 
e cultural brasileira, abordamos o referido confronto a partir da formulação do que denominaremos como duas imagens alegóricas, as quais condensam e imantam duas formas opostas de viver, nas quais os corpos, gêneros e sexualidades recebem especial atenção, porém a partir de duas perspectivas valorativas contrapostas entre si: uma que denominaremos de bolsonarista e outra que chamaremos de tropicalista. Cabe frisar que bolsonarismo e tropicalismo não são entendidos aqui como símbolos capazes de oferecer totalizações abrangentes e fechadas acerca da vida nacional, como se pudessem simbolizar um conflito entre duas dimensões acabadas de nossa identidade nacional ${ }^{3}$. Por outro lado, quando pensamos o bolsonarismo e o tropicalismo enquanto alegorias, os entendemos como constelações sociais cujos fragmentos ou estilhaços alegorizam e condensam dimensões significativas acerca de nossa conflitiva experiência histórica quanto aos corpos, gêneros e sexualidades, preservando-se, porém, o caráter de abertura e de incompletude dessas duas experiências contrapostas ${ }^{4}$. Segundo a perspectiva teórica adotada neste texto, não haveria que se esperar por qualquer síntese dialética dessa contraposição, muito menos que se supor que esse conflito possa ser um dia resolvido de uma vez por todas, em prol de apenas uma dessas duas figurações significativas. O que importa aqui é nomear e tornar inteligível o conflito entre essas duas dimensões cruciais

3 Pedro Duarte recorreu à distinção benjaminiana entre a alegoria e símbolo em sua análise do movimento Tropicalista. Segundo o autor (2018a, p. 7), "O Tropicalismo introduz na música popular do Brasil, mas também na imagem de Brasil que produz a partir dela, um sentido alegórico. Não se procura a perfeição que totalizaria a forma da canção e nem a imagem do país. Pelo contrário, encontra-se a força do estilhaço, dos fragmentos sem uma síntese. Sua intrusão pode 'ser caracterizada como um grande delito contra a paz e a ordem, no campo da normatividade artística'. O delito está na ausência de totalização simbólica. Isso que classicamente era dado como a fraqueza da alegoria, sua fragmentação, é o que Benjamin sublinha como a sua força particular, que quebra a ilusão de totalidade. Para tal, a alegoria, se é que tem uma dialética, é uma dialética muito particular, pois os opostos não vão se resolver - a tese e a antítese - em um terceiro termo: a síntese". Como veremos adiante, Ricardo Fabrini (2018) também contribuirá para o diálogo livre que estabelecemos com algumas ideias de Walter Benjamin neste artigo, como as de pensamento por imagens e de correspondência e afinidade entre o antigo e o atual. Não abordamos aqui as noções de messianismo e de revolução, centrais no projeto intelectual do historiador materialista benjaminiano.

4 Para uma discussão da concepção benjaminiana de história, na qual as noções de imagem dialética e de alegoria ocupam lugar central, veja-se o apartado N do projeto inacabado das Passagens de Walter Benjamin (2019), bem como suas "Teses sobre a História" (1986). Segundo Kátia Muricy, o "historiador-alegorista das 'Teses' trabalha com uma temporalidade intensiva, cujo modelo é o das obras de arte e das ideias. Ele irá quebrar a linearidade temporal, para obter os fragmentos com os quais construirá imagens que se oferecerão, como alegorias, à interpretação. (...) O historiador deve fazer explodir a continuidade homogênea de um tempo vazio, a linearidade do processo, e trabalhar com os fragmentos, com as ruínas do passado, cristalizados pelo olhar da atualidade, pela premência do perigo" (1999, p. 214). 
de nossa experiência acerca dos corpos, gêneros e sexualidades, as quais, por sua vez, são também dimensões cruciais para a qualificação de nossa vacilante experiência democrática.

Neste texto, entendemos o bolsonarismo e o tropicalismo como dois amálgamas, como duas cristalizações históricas significativas quanto ao reforço ou questionamento de parâmetros normativos hegemônicos a partir dos quais se atribuem significados para os corpos, gêneros e sexualidades no Brasil contemporâneo. Consideramos que o modo como tais experiências são vividas atualmente constitui um aspecto decisivo para a qualificação do potencial político da democracia brasileira, ao mesmo tempo em que também se encontra aí a sinalização dos riscos que assediam nossa democracia nos dias que correm. Tal relação entre democracia e movimentos políticos contranormativos, isto é, aqueles que contestam as normas sociais hegemônicas a partir de sua posição marginal em relação a elas, não tem sido suficiente e adequadamente considerada nas discussões filosófico-políticas acerca da democracia e de sua crise atual. Assim, propomos a hipótese de que a disputa político-estético-ético-cultural em torno do significado atribuído aos corpos, gêneros e sexualidades no Brasil contemporâneo não é secundária ou subsidiária para a determinação da qualidade da experiência democrática no país. Pelo contrário, pois tal embate condensa duas formas exemplares do viver em nossa atualidade, uma de claro viés autoritário e outra de claro viés libertário. Por um lado, há o ethos bolsonarista que reafirma e reforça as forças da ordem e da hierarquia patriarcal, heterossexual, cristã e fascinada pelo ideal da branquitude, condensados no ideal normativo do "Homem de Bem". (DUARTE, 2020a) Por outro lado, há o ethos tropicalista que designa aquelas manifestações políticas, estéticas, culturais e éticas que, ao longo dos últimos 50 anos, vêm atuando justamente no sentido da contestação daquela ordem normativa hierárquica. Embora tais figuras exemplares não esgotem ou totalizem o universo das possibilidades de existência no Brasil atual, acreditamos que essas duas experiências contrapostas do viver os corpos, os gêneros e as sexualidades incidem diretamente sobre o modo como se entende e se vive a experiência democrática no Brasil contemporâneo.

Abordemos, em primeiro lugar, bolsonarismo como imagem espelhada no ideal normativo do Homem de Bem. Ao menos em seu estágio atual, não parece justificável pensar o bolsonarismo como um movimento político coeso, dotado de forte organização institucional, burocrática e partidária, isto é, como um movimento político dotado de um consistente projeto de país, com uma ideologia política claramente discernível e bem 
delineada, como observou Newton Bignotto (2020). Ainda não é possível saber como esse movimento difuso evoluirá, mas são alarmantes os perigos que se deixam antecipar a partir de sua já evidente conexão com as milícias urbanas, que parecem sinalizar na direção de um conluio entre criminalidade e representação política (MANSO, 2020). Em vista de sua atual falta de consistência institucional e ideológica, o bolsonarismo se apresenta como um movimento político heterogêneo e um tanto amorfo. No entanto é inegável que o movimento encontra em Bolsonaro um líder político carismático capaz de galvanizar aspirações e convicções próprias do eleitorado de extrema-direita do país, visto que ele encarna e representa um claro conjunto de concepções conservadoras e reacionárias acerca de como devem ser a política e a vida nacionais, com ênfase muito especial quanto ao significado atribuído a corpos, gêneros e sexualidades, aspecto mais do que frequente em suas declarações públicas. Em sentido político estrito, o bolsonarismo representa diversas concepções antidemocráticas. Até o presente, o movimento se organiza politicamente em torno de um conjunto de negações e de recusas: é francamente contrário à diversidade populacional brasileira; é contra o reconhecimento do papel das mulheres, das populações negra e LGBTI, bem como dos povos tradicionais e originários na vida nacional, sendo, portanto, contrário ao reconhecimento e atribuição de direitos e dignidade a esses grupos sociais; é radicalmente contrário a toda forma de crítica, de ciência e de reflexão; despreza a igualdade de direitos, as políticas de proteção e incentivo às condições de vida das populações sujeitas a processos de vulneração, bem como é contrário à ideia mesma de pluralidade. O bolsonarismo é um fenômeno político autoritário e, na impossibilidade de romper definitivamente com a democracia brasileira, reivindica para si um entendimento bastante restritivo acerca do que seja a ordem democrática, amparando-se no modelo das democracias imunitárias e iliberais, democracias de fachada, fundamentadas no ódio às populações que não espelham as concepções do líder. (DUARTE, 2020a)

No entanto a identidade do bolsonarismo não se organiza apenas em torno de concepções políticas reacionárias e antidemocráticas, mas, sobretudo, em torno de valores e ideais conservadores, os quais imantam a vida cotidiana de boa parcela dos brasileiros e brasileiras. Assumimos aqui o pressuposto de que não se pode entender a política e as relações de poder apenas segundo a sua dimensão institucional, jurídico-política, mas também, e sobretudo, a partir da consideração do papel e da ação das normas sociais que orientam os pormenores da vida cotidiana. As normas, ao contrário das 
leis, possuem uma amplitude abrangente e uma sutileza penetrante, pois são capazes de orientar condutas e discursos, definindo e informando a forma mesma do viver. Dessa perspectiva, o bolsonarismo é um fenômeno político bastante consistente e bem enraizado na sociedade brasileira, mobilizando afetos, emoções, concepções e formas de vida que reproduzem ideais normativos já bem consolidados historicamente entre nós, os quais reforçam e acentuam clivagens e hierarquizações entre as formas de viver. Como nos ensinou Judith Butler (1990), tais modelos normativos ideais são sempre fantasmáticos, tanto porque não existem na realidade, motivo pelo qual devem ser continuamente reiterados e enfatizados, quanto porque produzem efeitos assustadores e muito reais no comportamento individual e coletivo. De uma perspectiva política mais ampla, portanto, parece-nos que o traço que melhor define e dá coesão ao bolsonarismo como movimento heterogêneo e um tanto disforme se encontra no ideal normativo do Homem de Bem. Essa figura normativa reúne uma diversidade de aspectos e dimensões da vida social brasileira, unificando-os em torno de valores conservadores, violentos e excludentes. Ela constitui um foco poderoso de produção de identificações e subjetivações, as quais, por certo, não deixam de incidir também sobre o comportamento das mulheres. Enquanto figura emblemática do ideal normativo do bolsonarismo, o Homem de Bem pode ser definido como conservador nos costumes, neoliberal quanto à economia e autoritário na política. Para os propósitos deste texto, interessa-nos abordar a dimensão conservadora quanto aos costumes, pois é a partir dessa instância que se disseminam as concepções normativas do bolsonarismo quanto aos corpos, gêneros e sexualidades.

Não pairam dúvidas quanto à centralidade do corpo, do gênero e da sexualidade na definição do bolsonarismo como amálgama de narrativas e de formas de vida reativas, que visam restabelecer uma suposta ordem natural das coisas. Essa reação conservadora é mundial, mas o Brasil ocupa lugar proeminente nesse movimento. De fato, como resposta às conquistas obtidas pelos movimentos feminista, negro e LGBTI em diversos países, as noções de corpo, gênero e diversidade sexual foram ressignificadas e transformadas em armas poderosas no contexto de uma intensa guerra cultural, política e moral. Tal guerra encontra na noção falaciosa de "ideologia de gênero" seu foco principal. No Brasil, essa guinada mundial hiperconservadora ganhou cor local por meio de movimentos reativos às políticas de enfrentamento do preconceito quanto à orientação sexual e à identidade de gênero levadas a cabo pelos sucessivos governos do Partido dos Trabalhadores. Não por 
acaso, o bolsonarismo fez sua primeira aparição pública de impacto e eficácia nacionais em 2011, no contexto de uma reação àqueles avanços políticos, escolhendo como alvo de sua reação legislativa o projeto Brasil sem Homofobia, o qual visava a elaborar suportes educativos para combater a homofobia, a lesbofobia e a transfobia nas escolas (CÉSAR E DUARTE, 2017). Em termos pejorativos, o projeto foi designado publicamente como o "kit gay" por parlamentares conservadores, por fundamentalistas religiosos e por parte da grande mídia, iniciando-se assim o processo de acirramento do "pânico moral" (RUBIN, 1993), em vista do qual polêmicas agressivas em torno de questões relativas à definição dos gêneros e da orientação sexual assumem proporções desmesuradas. Foi no curso desse processo reativo que as noções de igualdade de gênero e raça/etnia, assim como a noção quanto ao respeito à diversidade sexual, foram excluídas do Plano Nacional de Educação - PNE (BRASIL, 2014). Foi assim, também, que, durante as eleições presidenciais de 2018, a fake news sobre a temível "mamadeira de piroca" tornou-se um poderoso instrumento de campanha política a favor da eleição de Jair Bolsonaro, sobretudo entre o eleitorado neopentecostal. Não faz sentido, portanto, considerar a ênfase atribuída aos corpos, gêneros e sexualidades pelo bolsonarismo como mera cortina de fumaça visando a encobrir outros e mais verdadeiros interesses políticos e econômicos do movimento. Essa concepção equivocada impede de entender o impacto e a eficácia de seu apelo conservador, o qual apresenta forte poder aglutinador e opera de maneira a unificar um movimento político ultraconservador, mas cujos apoiadores possuem perfis sociais, culturais e econômicos bastante variados, carecendo de clara e imediata identidade entre si. Assim, a restituição da ordem hierárquica tradicional entre corpos, gêneros e práticas sexuais tornou-se um elemento central para a definição de alianças entre grupos sociais distintos, porém igualmente assombrados com o espectro de um suposto fim da família tradicional. Como afirmou Luiz Eduardo Soares, "Clama-se por ordem ante um mundo de incertezas, em que as referências valorativas e as âncoras ontológicas se deslocam desde os modelos de família até os modos de construção da identidade e as formas de amor" (2019, ed. Kindle).

Em certo sentido, o recente fortalecimento do bolsonarismo enquanto ethos socialmente espraiado nos devolve ao ambiente nacional de finais dos anos 1960 e início dos anos 1970, com seu apelo à ordem militar, exaltação da pátria, pavor ao perigo vermelho do comunismo e o ódio às populações minoritárias. Acrescente-se ainda o sintomático rechaço 
do "politicamente correto", entendido como poderosa arma cultural de uma suposta ditadura minoritária que teria calado e oprimido os defensores da boa ordem patriarcal, heterossexual, cristã e aspirante a uma branquitude idealizada. O armário embolorado do conservadorismo brasileiro foi escancarado e dele saiu triunfante o ideal fantasmático do Homem de Bem, que ganhou as ruas, avenidas e redes sociais até se instalar no Planalto Central do Brasil. Não terá sido por acaso, portanto, que um dos sinais mais evidentes da crise contemporânea da democracia brasileira tenha se evidenciado no recente acirramento dos discursos e das ações violentas que visam deslegitimar a condição de cidadania daquelas parcelas da população que podem ser consideradas como marginais ou como minoritárias do ponto de vista de seu desvio em relação à normatividade social prevalecente, como as mulheres, as populações negra e LGBTI, os povos originários e tradicionais (DUARTE, 2020b). Em outros termos, é preciso pensar a crise da democracia contemporânea em sua intrínseca relação com a disseminação de um modo autoritário de ser-no-mundo, o qual já não se vale mais apenas das estratégias de inclusão normalizadora das diferenças, pois já não teme promover abertamente estratégias de governamento que passam pela produção de formas variadas de estigmatização e de exposição à morte daquelas parcelas da população que se encontram às margens do centro normativo hegemônico do bolsonarismo. Pode haver democracia digna desse nome num contexto político, social, cultural e econômico no qual se incentivam práticas e discursos de ódio e violência contra populações historicamente sujeitas a processos de vulneração e precarização? Pode haver democracia em sentido forte na ausência de um questionamento radical dos padrões normativos que discriminam quais corpos contam e quais são descartáveis, incluindo-se aí a questão racial brasileira, com suas múltiplas implicações estruturais e institucionais? Pode haver democracia digna de consideração sem que se questionem as profundas dissimetrias que marcam as experiências do masculino e do feminino entre nós? Pode haver democracia sem o questionamento crítico acerca das hierarquias valorativas que se traduzem em violências e discriminações fundadas no primado da heteronormatividade e do fundamentalismo cristão?

É justamente nesse contexto de urgência e de perigo, isto é, de crise aguda da democracia brasileira, que nos parece mais do que oportuno e urgente retomar a reflexão acerca do tropicalismo como imagem alegórica exemplar acerca das atitudes críticas em relação à figura normativa do Homem de Bem ao longo da história brasileira recente. Para tanto, algumas 
questões se colocam já de saída: como considerar o tropicalismo enquanto exemplo de atitude crítica ainda válida em nossos dias sem incorrer em anacronismos e reducionismos? Como escapar à lógica mais do que duvidosa das influências e do modelo metafísico que contrapõe o original à cópia? Como evitar o apagamento da diversidade histórica das manifestações políticas, estéticas e culturais brasileiras dedicadas à crítica das hierarquias e significados tradicionais vinculados aos corpos, gêneros e sexualidades ao longo dos últimos 50 anos? Para responder a essas questões, é preciso, em primeiro lugar, deixar de lado a ideia de que qualquer aspecto da experiência histórica, política, cultural e estética brasileira da virada dos anos 1960 pudesse ser revivida tal e qual em nosso tempo. Tudo mudou e o passado jamais retorna ou se repete enquanto tal; o que, por outro lado, tampouco significa que o passado tenha passado de uma vez por todas, pois "nada do que um dia aconteceu pode ser considerado perdido para a história", como nos recorda Walter Benjamin (1986, p.223). Outro aspecto crucial para nosso propósito requer não considerar o tropicalismo apenas como movimento estético-político determinado e datado, e muito menos como uma origem que se prolongaria ao longo do tempo, influenciando movimentos estéticos e políticos de épocas posteriores.

Por outro lado, procuramos pensar a Tropicália ou o Tropicalismo como um movimento estético-político que inspirou o tropicalismo como ethos exemplar, isto é, como imagem alegórica que condensa atitudes de crítica e de contestação social que, ao longo dos últimos 50 anos, confrontaram os significados tradicionais atribuídos aos corpos, gêneros e sexualidades ${ }^{5}$. Nesse sentido, o tropicalismo seria uma imagem instantânea capaz de reunir fragmentos de contestações e de experimentações do passado que ainda restam abertas e atuais para nossa atualidade, pois jamais se cumpriram. Ao pensar o tropicalismo como ethos e como imagem alegórica, o concebemos como instância decisiva para a nomeação, para o reconhecimento e para a própria constituição de modos radicalmente democráticos de coexistir no agora de nosso país. Noutros termos, procuramos entender o Tropicalismo como um movimento estético-político que transcendeu sua época e o domínio da cultura, transmitindo-se ao longo da história brasileira recente

5 Para marcar a diferença, o que estamos chamando de tropicalismo como ethos e imagem alegórica será sempre grafado em minúsculas, ao passo em que o Tropicalismo ou a Tropicália como movimento estético serão sempre redigidos em maiúsculas. 
como herança desprovida de testamento, mas cuja potência plasmadora teria feito dele um signo duradouro, capaz de inspirar múltiplas e diversas maneiras críticas e inconformistas de co-habitar em nosso país. Sob tal perspectiva, o tropicalismo carregaria consigo certos vetores difusos, inespecíficos, talvez até mesmo inconscientes, vinculados à contracultura e seus questionamentos múltiplos e diversificados acerca das violências e dissimetrias relacionadas às nossas experiê ${ }^{6}$ êneros e as sexualidades. Nesse sentido preciso, o Tropicalismo não seria uma origem, mas o acontecimento da emergência renovada de múltiplas e reiteradas experiências de contestação cultural e política em torno do significado atribuído aos corpos, gêneros e sexualidades. Assim, o tropicalismo é pensado aqui como um arquivo vivo, de cujo arcabouço continuam a brotar inúmeros exemplos de contestação cujos significados se renovam historicamente, mas que, nem por isso, perdem contato com experiências já trilhadas em outros tempos e de outros modos. Desse ponto de vista, o tropicalismo é aqui reconhecido como índice daquele "encontro secreto, marcado entre as gerações precedentes e a nossa", como certa vez sugeriu Walter Benjamin. (1986, p. 223) Neste ensaio, portanto, o tropicalismo é considerado como constelação cujas fagulhas cintilantes estabelecem afinidades e correspondências instantâneas entre passado e presente, conferindo sentido e inteligibilidade a uma multiplicidade de manifestações e experiências estéticas, éticas, políticas e culturais dedicadas à contestação e à denúncia dos parâmetros normativos hegemônicos, os quais expõem os corpos, gêneros e sexualidades dissidentes ao risco da violência e da morte no Brasil.

As considerações precedentes devem servir como advertência a fim de que não se espere deste artigo uma análise aprofundada e específica acerca da Tropicália como movimento estético determinado e datado. Assim, se a partir de agora nos dedicamos a um breve comentário sobre alguns aspectos específicos daquele movimento estético, nós o fazemos apenas a fim de chamar a atenção para a ênfase contestatória que nele se conferiu aos corpos, às sexualidades e aos gêneros, aspecto que, por certo, não passou de todo despercebido aos seus principais estudiosos. Em texto recente, Pedro Duarte

6 Seguimos aqui a sugestão proposta por Guillaume Le Blanc em seu Philosophie comme contre-culture, livro em que ele defende a ideia de que "A contracultura é o ato cultural de se voltar contra os esquemas sociais e políticos hegemônicos. Ela é, neste sentido, uma crítica suscitada pelas possibilidades de vida recobertas pelas construções culturais da dominação" (2014, p. 5). 
(2020) observou que a potência das canções tropicalistas era indissociável da performance corporal e visual dos seus intérpretes, tornada acessível por meio das transmissões televisionadas de suas aparições. Assim, no III Festival Internacional da Canção, promovido em 1968 pela Rede Globo, Gilberto Gil entrou no palco vestindo uma túnica colorida africana, ao passo que Caetano Veloso, acompanhado do grupo Os Mutantes, vestia um terno de plástico verde-limão e preto, bem como exibia gestual nitidamente sexual, acrescido dos urros e gemidos de um hippie contratado para o happening (DUNN, 2009, pp. 157 e 158) da apresentação performática de "É Proibido Proibir". A canção, que se inicia constatando que a "A mãe da virgem diz que não", irritou e desconcertou o público, que não apenas vaiou estrondosamente o grupo como atirou ovos, tomates e pedaços de pau na direção do palco, enquanto Caetano Veloso pronunciava o famoso discurso no qual interpelava criticamente a plateia: "Mas é isso que é a juventude que diz que quer tomar o poder?" (DUARTE, 2018b, p. 111). Naquela noite de 15 de setembro de 1968, ninguém ainda parecia preparado no Brasil para uma proposta estético-política libertária e que fundia "rock, política radical francesa e o poema épico de Pessoa", combinação cujo ecletismo sugeria o "escopo trans-histórico e internacional da música" (DUNN, 2009, p. 159),

Ainda em meio ao efeito perturbador provocado pela aparição abrupta do movimento da Tropicália, Hélio Oiticica enfatizou o caráter anárquico e vanguardista das suas performances, as quais escapavam às ideologias fechadas justamente na medida em que abraçavam novas experiências criativas. Segundo Oiticica, "Caetano veste-se como quer, não por loucura premeditada para ganhar dinheiro (...), sua intenção fundamental quando diz que deseja 'quebrar estruturas' é exatamente abrir-se a todas as demandas de sua imaginação criadora" (OITICICA, 2008, p. 165). Desse modo, a proposta-manifesto de "É Proibido Proibir" poderia ser assim traduzida: "se quero ficar nu, fico; se quero usar colares, roupa de plástico, uso - o mesmo que dizer: faça isso você também, se o quiser, ou faça o que quiser, como eu o faço" (OITICICA, 2008, p. 165). Para o artista plástico, a incorporação daqueles elementos vanguardistas e anárquicos às performances dos Tropicalistas não poderia ser considerada como algo externo, superposto ou meramente "acessório à sua música", pois tudo aquilo fazia parte do próprio processo criativo. Dentre outros, também Celso Favaretto observou em seu estudo clássico que o "tropicalismo reentronizava o corpo na canção, remetendo-a ao reencontro com a dimensão ritual da música, exaltando o que de afeto nela existe" (FAVARETTO, 1996, p. 35), Nessa mesma linha 
argumentativa, Pedro Duarte ressaltou que, para os Tropicalistas, o corpo demandava uma outra estética e uma outra política, uma outra maneira de viver. Por isso, considerou que a canção Tropicalista aliava "experimentação musical" e "erotização do corpo, micropolítica e performance visual e discursiva. O movimento, junto à contracultura dos anos 1960, era música e, simultaneamente, gesto, atitude" (DUARTE, 2018b, p. 49). Seguindo o fio condutor da oposição entre rebelião e revolução, tal como proposta por Octávio Paz, Pedro Duarte também chamou a atenção para o fato de que a Tropicália permitiu a entrada em cena de um corpo que já não era mais apenas o objeto explorado pelas relações de trabalho, segundo o viés do marxismo, pois aquele "era também um corpo da dança, do sexo, do prazer" (2020, p. 8).

Já no final dos anos 1970, Heloísa Buarque de Hollanda observara que o Tropicalismo como movimento estético abandonara a preocupação marxista em projetar o amanhã a ser instaurado pela revolução ao dedicar sua atenção ao "aqui e agora", bem como ao "pensar a necessidade de revolucionar o corpo e o comportamento, rompendo com o tom grave e a falta de flexibilidade da prática política vigente" (2004, p. 70). Não nos esqueçamos de que foi justamente por causa dessa "crítica comportamental" e pelo "deboche diante das atitudes "bem-comportadas" (BUARQUE DE HOLLANDA, 2004, p. 70) que Gilberto Gil e Caetano Veloso foram presos e exilados por dois anos e meio pelos militares, depois de permanecerem incomunicáveis por dois meses. A esse respeito, há uma passagem elucidativa no recente documentário de Renato Terra e Ricardo Calil, "Narciso em Férias" (2020), em que Caetano Veloso lê os autos de sua prisão e interrogatório em 1968, no qual é acusado, dentre outras coisas, de produzir músicas de conteúdo "subversivo" e "desvirilizante". Em outra passagem do documentário, ele se recorda de um sinistro militar, treinado nos Estados Unidos para o combate à subversão, para quem o Tropicalismo seria muito mais perigoso que as tradicionais canções de protesto, pois teria se inspirado nas lições de Herbert Marcuse e em seu projeto de "terrorismo cultural", para desestruturar os valores familiares tradicionais (VELOSO, 1997, p. 279; DUNN, 2008, p. 173).

Outra contribuição importante de Heloísa Buarque de Hollanda reside em sua observação de que, a partir daquelas propostas estéticopolíticas, operava-se um importante deslocamento, visto que a "identificação" de parte da juventude inconformista já não se dava mais com o " "povo" ou o "proletariado revolucionário", mas com as "minorias", em sintonia com a "disposição libertária do Tropicalismo" (2004, p. 75). Foi também nesse 
ambiente cultural marcado pelo Tropicalismo, pelo pós-Tropicalismo e pelo "desbunde" de meados dos anos 1970 que os trabalhos de Michel Foucault começaram a desempenhar importante papel no Brasil. Segundo Buarque de Hollanda, "A discussão do poder, que já estava colocada para a tendência pós-tropicalista, passa a ser veiculada agora enquanto preocupação teórica e os trabalhos de Michel Foucault ... desempenham um importante papel no debate" (2004, p. 104). Assim, no Brasil dos anos 1970 e 1980, o interesse pelas obras de Foucault surgia "da necessidade de uma discussão conceitual a respeito de uma atitude já presente em setores jovens da produção cultural e na experiência de vida de significativas parcelas da população" (2004, p. 105). Ora, parece-nos que essa sinergia entre a reflexão foucaultiana e algumas atitudes contraculturais bastante significativas para a vida de parcelas importantes da população brasileira jamais se interrompeu totalmente entre nós. Com o movimento estético-político da Tropicália parecem ter sido lançadas as sementes de uma atitude crítica tropicalista, cujo élan contestador certamente se transformaria e se transfiguraria ao longo do tempo, sem, contudo, jamais desaparecer da cena político-cultural brasileira.

Uma vez estancado o impacto devastador provocado pela epidemia do HIV-AIDS, para o que, certamente, o movimento LGBT contribuiu de maneira decisiva ao longo dos anos 1990, houve entre nós desde o início do século XXI um crescente e consistente movimento na direção da politização dos corpos, dos gêneros e das sexualidades. Esse movimento politizador transcendeu o ambiente político institucional e assumiu a forma de experimentações políticas, estéticas e culturais em sentido lato, o que se confirma com a multiplicação de coletivos LGBTI autônomos e horizontalizados. Dentre eles, podemos mencionar a Marcha das Vadias, coletivo que esteve bastante ativo em todo país entre os anos de 2011-2014, com suas performances estético-políticas que faziam do corpo nu o suporte para o protesto e a demanda por pautas feministas e LGBTI (CÉSAR e DUARTE, 2017). Ao clima anárquico que caracterizava as manifestações daqueles novos coletivos urbanos, os quais atuavam sem estatutos, líderes, representantes ou hierarquias - aspectos que os distinguiam de outros movimentos sociais das grandes cidades - somava-se ainda o fato crucial de que tais grupos praticavam uma política corporal, isto é, uma política do corpo ou uma política como corpo-a-corpo no espaço público, disseminando imagens poderosas pelas redes virtuais e pela mídia. Na perspectiva daqueles coletivos, se o corpo é o lugar privilegiado da inscrição de múltiplas formas de sujeição e violência na cidade, então o corpo também deveria ser convertido 
em palco do combate político cotidiano por novas possibilidades de existência em comum, menos violentas e discriminadoras, mais democráticas e criativas. Coletivos como o Marcha das Vadias sinalizavam a possibilidade de uma politização da vida que visava a promover curto-circuitos nos sistemas normativos hegemônicos de regramento e normalização da vida urbana, convertendo a fragilidade do mero corpo exposto a toda sorte de riscos e violências em nova força política. Contra a redução da vida ao estatuto de vida nua e desprotegida, tais coletivos promoviam a ressignificação do corpo por meio da aparição inusitada do corpo nu ali onde não esperaríamos encontrá-lo, isto é, no meio da rua.

Esse ambiente de agitação político-cultural repercutia, ainda que tardiamente, a abertura da democracia brasileira para as lutas políticas orientadas por ideais contestatórios contraculturais, duramente reprimidos pela ditadura civil-militar de 1964, sobretudo a partir de 1968, com o AI5. Não por acaso, àquela época, produziram-se no Brasil interessantes documentários cinematográficos como Uma noite em 67, de Renato Terra e Ricardo Calil (2010); Dzi Croquettes, de Tatiana Issa e Raphael Alvarez (2009); além de alguns filmes oriundos da nova onda do cinema recifense, tais como Febre do Rato, de Claudio Assis (2012) e Tatuagem, de Hilton Lacerda (2013). Uma noite em 67 tem seu foco narrativo na final do III Festival de Música Popular Brasileira promovido pela TV Record, marco da primeira aparição do movimento estético que, logo a seguir, viria a ser denominado como Tropicália ou Tropicalismo. Assistir ao documentário é como receber um sopro de ar fresco no rosto, e isto, justamente quando a fresta para a renovação político-cultural do país estava prestes a se fechar, às vésperas do AI-5. Como teria sido o Brasil se a ditadura não tivesse durado duas décadas? Por sua vez, o documentário Dzi Croquettes explora o radical embaralhamento das relações de gênero nas performances glamorosas e provocativas de um famoso grupo teatral de bailarinos do Rio de Janeiro do início dos anos 1970, já em meio aos anos de chumbo, quando a ditadura se tornara ainda mais sanguinária. Naquele contexto mais do que improvável, um grupo de jovens talentosos, inconformistas e iconoclastas se reuniu e montou um espetáculo no qual dançavam, cantavam e interpretavam papeis que punham em xeque os binarismos de gênero e a heterossexualidade. Portando trajes femininos, hipermaquiados, mas sem jamais ocultar os traços de seus corpos masculinos, a estética ambígua dos Dzi Croquettes valia-se do humor debochado e do talento para promover uma crítica radical dos 
valores dominantes, promovendo um carnaval antirepressivo que não tardou a despertar a ira dos censores e da polícia.

Por sua vez, o filme Tatuagem, ao recontar ficticiamente as experiências de coletivos teatrais recifenses de finais da década de 1970, encenava a permanência daquele espírito camp, com seu caráter marginal e questionador quanto aos significados tradicionais conferidos aos corpos e à sexualidade. $\mathrm{O}$ filme de Hilton Lacerda mostra que o corpo pode ser um instrumento de amor, de erotismo, de beleza e de luta política contra a rigidez do conservadorismo moral que prevaleceu no país ao longo da ditadura e que ainda hoje assedia nossa frágil democracia. O filme estabelece um diálogo entre o presente narrado, cuja história se desenrola no ano de 1978, e o futuro ao qual pertencem os espectadores de 2013. Essa ponte temporal é reforçada pelo personagem do filho quase-adolescente de Deusa e Clécio, e pelo filme dentro do filme, com o qual Hilton Lacerda homenageia o cineasta experimental Jomard Muniz de Britto, que, nos anos 1970, documentou em super-8 as atividades do grupo teatral Vivencial Diversiones, do Recife, ao qual alude o Cabaré Chão de Estrelas. No filme dentro do filme Lacerda produz imagens oníricas, de forte apelo alegórico, imagens-totêmicas para nós brasileiros: índios e índias, sambistas, bichas, sapatões e travestis em festa. A essas imagens, associam-se aquelas que aludem ao futuro de uma civilização tecnológica periférica e que tenta se arranjar com o pouco de que dispõe, como é o caso do astronauta feito de latas e bugigangas, caminhando desorientado em meio a bananeiras e índias que o veneram espantadas. Ainda mais fundamentalmente, essa conexão temporal entre passado e presente se deixa perceber no próprio título do filme: afinal, a tatuagem é uma inscrição que fere o corpo para exibir uma mensagem que não mais se apaga, que dura no tempo, estabelecendo assim um elo de ligação entre presente, passado e futuro.

Finalmente, Febre do rato retoma aspectos daquelas mesmas problematizações anteriores sobre o corpo, a sexualidade e as relações comunitárias, mas as situa em pleno Recife da segunda metade do século XXI. Claudio Assis, assim como também Hilton Lacerda, filma experiências heterotópicas de uma vida comunitária outra, alternativa, estranha, pois despojada de rígidas hierarquias ou de procedimentos de inclusão normalizadora de seus integrantes, uma comunidade dos 'sem' comunidade, desprovida de identidades fixas ou de projetos políticos bem formulados, mas na qual o corpo, o amor e o prazer tornam-se instâncias anárquicas de contestação e de luta micropolítica. Dzi Croquettes, Tatuagem e Febre do 
rato nos permitem compreender um pouco melhor o significado daquela "inversão tática" por meio da qual Foucault nos convidava a "opor os corpos, os prazeres, os saberes, em sua multiplicidade e sua possibilidade de resistência às captações do poder" (FOUCAULT 1999, p. 147). Para Foucault, tratava-se de promover lutas pelas quais pudéssemos nos liberar da monótona monarquia do sexo-desejo e de seus avatares, como o machismo viril e a heterossexualidade como matriz normativa exclusiva e excludente. Os três filmes podem ser entendidos como crônicas da vida artística vivida em comum, como crônicas contemporâneas das vidas infames, vividas coletivamente à margem dos conceitos e preconceitos normativos que insistem em promover vigilâncias, violências e assassinatos (DUARTE, 2017).

Ora, como não reconhecer correspondências e afinidades eletivas entre as manifestações estético-políticas do Tropicalismo, as experiências narradas em Dzi Croquettes, Tatuagem e Febre do Rato e manifestações políticas de inspiração queer, como a Marcha das Vadias? Ontem, como hoje, o deboche cínico, a criatividade espontânea e instantânea, a contestação dos padrões normativos de gênero, sexualidade e etnia, parecem ainda anunciar melhores promessas de futuro. Tais manifestações alternativas de contestação estética, política, ética e cultural parecem documentar o interesse continuamente renovado da cultura e da política brasileiras por manifestações seminais da contracultura. Sem que se pretenda negar seu caráter fragmentário e descontínuo, sugerimos que aquelas fulgurações instantâneas são como uma "reminiscência" que "relampeja no momento de um perigo" (BENJAMIN, 1986, p. 224)7.

Por certo, essas breves reaparições transfiguradas do ethos tropicalista ao longo da história brasileira recente merecem maior investigação e análise mais aprofundada. Evidentemente, tudo mudou entre os finais dos anos 1960 e a segunda década do século XXI. No entanto, parece-nos que aquele movimento cultural e político que, na virada dos anos 1960-1970, constituiu um impulso rebelde e criativo no campo da cultura e das artes,

7 Nas Passagens, Benjamin se expressa nestes termos: "Não é que o passado lança sua luz sobre o presente ou que o presente lança sua luz sobre o passado; mas a imagem é aquilo em que o ocorrido encontra o agora num lampejo, formando uma constelação. Em outras palavras: a imagem é a dialética na imobilidade. Pois, enquanto a relação do presente com o passado é puramente temporal, a do ocorrido com o agora é dialética não de natureza temporal, mas imagética. Somente as imagens dialéticas são autenticamente históricas, isto é, imagens não arcaicas. A imagem lida, quer dizer, a imagem no agora da cognoscibilidade, carrega no mais alto grau a marca do momento crítico, perigoso, subjacente a toda leitura" (2019, p. 768). 
pouco a pouco transbordou para fora do domínio da estética (sem abandonálo, evidentemente) e se disseminou numa miríade de manifestações éticopolíticas voltadas para a politização da vida e para a contestação dos efeitos de poder associados aos critérios normativos que conferem sentido social aos corpos, gêneros e orientações sexuais. Assim, em contraste e a despeito da hegemonia reacionária vigente em nosso tempo, cumpre observar que os movimentos LGBTI, os movimentos feministas e os movimentos negros seguem cada vez mais ativos. Igualmente, nunca antes houve entre nós tanta atenção e interesse pelas epistemologias decoloniais, com sua ressignificação do valor das culturas dos povos originários e a intensificação das novas pautas ecológicas. Nesse sentido, parece-nos importante reconhecer nossa dívida para com o Tropicalismo e para com o ethos singular que dele se desprendeu, com seu deboche, sua ironia crítica, sua recusa das ideologias fechadas e seus projetos utópicos para o amanhã, sua desconfiança para com a burocratização dos aparatos partidários, seu inconformismo para com as mais explícitas e as mais insidiosas violências e as discriminações, enfim, para com seu espírito de politização cotidiana dos corpos, gêneros e sexualidades desviantes. Por caminhos diversos, chegamos a uma conclusão próxima à proposta por Luiz Eduardo Soares, para quem "o tropicalismo foi e ainda é fundamental para a história dos direitos humanos no Brasil, para a metabolização cultural não dos conceitos intelectuais, mas dos sentimentos, dos valores e das experiências que lhes dão sentido" (2019, ed. Kindle).

Sem dúvida, não faria sentido pretender mitificar a Tropicália, movimento estético-político que buscou justamente superar o mito da identidade nacional, questionando a própria ideia de unidade simbólica da cultura brasileira, um movimento de papel crepom e prata que armou uma bricolagem de fragmentos caleidoscópicos do Brasil. Como argumentou Ricardo Fabrini, a "atualidade da canção tropicalista" residia em que, mesmo diante dos anos mais duros da repressão ditatorial, ela nos mostrava ser possível "transformar a ausência de uma identidade estável em potência de libertação" (2018, p. 26), De maneira similar, neste ensaio, não se tratava, portanto, de achatar singularidades estéticas e políticas numa síntese acabada de todas as manifestações rebeldes e criativas tornadas possíveis desde e pela própria Tropicália. Como ressaltou Luiz Eduardo Soares, "O tropicalismo demonstrou que é viável afirmar identidades, pronunciar-se criticamente e marcar diferenças, embora também abraçando alteridades, reconhecendolhes a força e a dignidade estético-cultural" (2020, ed. Kindle). Para além de uma consideração detida e especializada acerca do Tropicalismo, tratava-se 
de considerar o tropicalismo como alegoria viva, tensionada, fragmentada, aberta e criativa, capaz, portanto, de relampejar num momento de perigo e, assim, iluminar múltiplas figuras da resistência ao longo dos últimos 50 anos, estabelecendo um regime de troca, comunicação e partilha. Se procuramos estabelecer esse laço discreto entre presente e passado, não o fizemos para detectar límpidas continuidades no nível da reconstituição histórica de positividades entre um momento e outro, mas porque consideramos que a detecção e nomeação dessas fulgurações historicamente reiteradas nos indica para onde olhar a fim de encontrar novas instâncias políticas de produção de choques e tensões contra a ordem predominante em nosso tempo. Tais reiterações sutis sugerem que, no plano das manifestações estéticas, éticas, políticas e culturais de questionamento das formas de viver, nada foi inventado hoje e, portanto, jamais estivemos sozinhos nessa hora triste que hoje nos tocou viver: temos lastro, temos histórias, temos antecessores, temos possibilidades que restam ainda atuais porque não foram cumpridas, algo que nunca é demais recordar aos mais jovens e a nós mesmos. Assim, concordamos uma vez mais com Ricardo Fabrini quando ele afirma que "No carnaval tropicalista há consciência histórica, um 'trabalho da cultura' de elaboração da tradição que produz tanto a ruptura com o passado quanto a irrupção no presente de suas possibilidades ainda não realizadas" (FABRINI, 2018, p. 26). Em suma, tratava-se apenas de recordar que temos um passado cheio de novidades, prontas a serem transfiguradas e reatualizadas em nossos dias. Tratava-se, pois, de permanecer naquele campo das fricções políticas que garantem a abertura da história, continuamente rasgada pela força dos estilhaços que impedem a cimentação da paz e da ordem.

\section{Referências Bibliográficas}

BENJAMIN, WALTER. Passagens, vol. II. Belo Horizonte: Editora da UFMG, 2019. Organização por Willi Bolle em colaboração com Olgária C. F. Matos; tradução do alemão por Irene Aron; tradução do francês por Cleonice P. B. Mourão; revisão técnica por Patrícia de Freitas Camargo.

BENJAMIN, W. Obras escolhidas. Magia e técnica, arte e política. São Paulo: Brasiliense, 1986, $2^{a}$ ed. Tradução de Sérgio Paulo Rouanet. 
BIGNOTTO, NEWTON. O Brasil à procura da democracia. Da proclamação da República ao século XXI (1889-2018). Rio de Janeiro: Bazar do Tempo, 2020. Edição Kobo.

BRASIL. Lei no 13.005 , de 25 de junho de 2014. Aprova o Plano Nacional de Educação (PNE) e dá outras providências. Câmara dos Deputados, Edições Câmara, Brasília, 2014.

BUARQUE DE HOLLANDA, H. Impressões de Viagem. CPC, vanguarda e desbunde. Rio de Janeiro: Aeroplano, 2004, 5a. ed.

BUTLER, JUDITH. Gender Trouble. Feminism and the subversion of identity. Nova York: Routledge, 1990.

CAMINHA, P. V. "Carta de Pero Vaz de Caminha" in Brasil: Ministério da Cultura. Fundação Biblioteca Nacional. Departamento Nacional do Livro, s.d. http://objdigital.bn.br/acervo_digital/livros_eletronicos/carta.pdf Consultado em 12.09.2020.

CÉSAR, MARIA RITA DE ASSIS; DUARTE, ANDRÉ. "Governamento e pânico moral: corpo, gênero e diversidade sexual em tempos sombrios." In Educar em Revista. Vol. 33, n. 66, 2017.

DUARTE, ANDRÉ. A pandemia e o pandemônio: ensaio sobre a crise da democracia brasileira. Rio de Janeiro: Via Verita, 2020a.

DUARTE, A. "Democracia em crise: biopolítica e governamento neoliberal de populações." In Revista Educação e Filosofia (ONLINE), v. 33, p. 527$562,2020 \mathrm{~b}$.

DUARTE, A. "Foucault vai ao cinema: Tatuagem e Febre do Rato como desgoverno das identidades sexuais." In Filosofia. Coleção Ensaios Brasileiros Contemporâneos. Org. Pedro Duarte; Luciano Gatti; Ernani Pinheiro Chaves. Rio de Janeiro: FUNARTE, 2017.

DUARTE, PEDRO. "O corpo presente da Tropicália". Texto inédito apresentado no Colóquio Literaturas e Artes de Corpo presente, realizado na PUC-RJ em 2020.

DUARTE, P. "A alegoria Tropicalista do absurdo." In VISO - Cadernos de Estética Aplicada. Rio de Janeiro: vol. 23, julho-dezembro de 2018a.

DUARTE, P. O livro do disco: Tropicália ou Panis et Circensis. Rio de Janeiro: Cobogó, 2018b. 
DUNN, CHRISTIAN. Brutalidade jardim. A Tropicália e o surgimento da contracultura brasileira. São Paulo: Unesp, 2009.

FABRINI, RICARDO. “A atualidade do Tropicalismo". In VISO - Cadernos de Estética Aplicada. Rio de Janeiro: vol. 23, julho-dezembro de 2018.

FAVARETTO, CELSO. Tropicália: alegoria, alegria. São Paulo: Ateliê, 1996.

FOUCAULT, MICHEL. História da Sexualidade. Vol. 1, A vontade de saber. Rio de Janeiro: Graal, 1999. Tradução de M. T. C. de Albuquerque e J. A. G. de Albuquerque.

LE BLANC, GUILlAUME. Philosophie comme contre-culture. Paris: Presses Universitaires de France, 2014.

MANSO, BRUNO PAES. República das Milícias. Dos esquadrões da morte à era Bolsonaro. São Paulo: Todavia, 2020. Edição Kindle.

MURICY, KATIA. Alegorias da Dialética. Rio de Janeiro: Relume-Dumará, 1999.

OITICICA, H. "A trama da terra que treme." In Tropicália. Encontros. Organizado por Sérgio Cohn e Frederico Coelho; Apresentação por Fred Orey. Eio de Janeiro: Beco do Azougue, 2008. Esse texto também se encontra disponível em http://tropicalia.com.br/eubioticamente-atraidos/ verbo-tropicalista/a-trama-da-terra-que-treme Consultado em 1.10.20.

RUBIN, G. "Thinking sex. Notes for a radical theory of the politics of sexuality." In: ABELOVE, H.; BARALE, M. A.; HALPERIN, D. M. (Ed.). The lesbian and gay studies reader. New York: Routledge, 1993.

SOARES, LUIZ EDUARDO. O Brasil e o seu duplo. São Paulo: Todavia, 2019. Edição do Kindle.

VELOSO, C. São Paulo: Cia. das Letras, 1997.

RECEBIDO EM: 15/03/2021

APROVADO EM: 05/04/2021 